\title{
二重配列型および三重配列型 定在波電界カーテンの理論特性
}

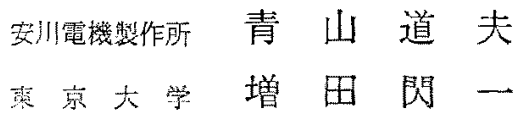

\section{1.まえがき}

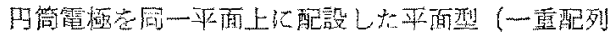
型）の電界カーテンについては，篗者らの一人に上っ

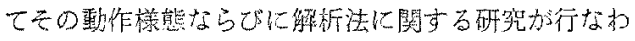

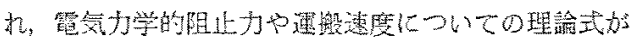

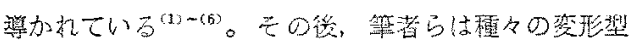

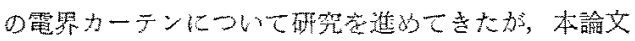

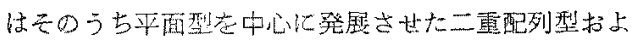

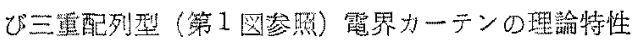

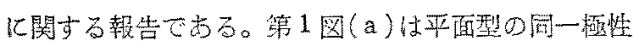

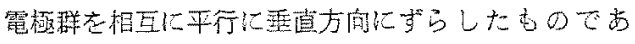
b，(b)図の二重配列型は千鳥配列型での同一榀维群

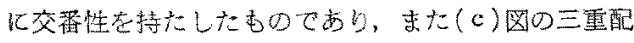
列型は (b)図のパターンの繰り返しでする。また研究 の効象之した事項は，乙扎らの麗界力ーテンの電位関 数心決定上応用上重要な電気力学的な组止ポテンシャ ルおよび阻止力の理諭特性の解明である。従来研究さ

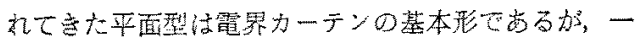
方, 電界力ーテン装策としての組文立てやすさとか, あるいは性能の斡てえなどの意味で二重配列型，三重

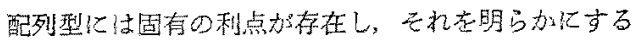
のが本研究の目的で古る。

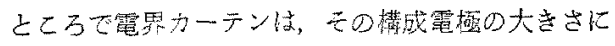
上って次の三つのグルーブに分類できる。

Theoretica! Characteristics of Double-array and Triplemarray Electric Cartaing of Standing Wave Type. By Michio AOYAMA, Member (Yasukawa Electrie Mig. Co., Ltd.) \& Senichi MASUDA, Member (Faculy of Engineering. University of Tokyo)

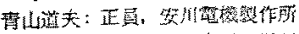

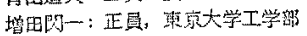

昭 $50-12$

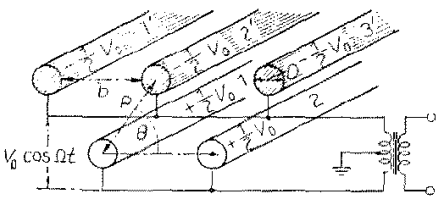

(a) 干霹翻到型

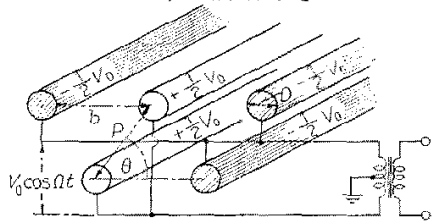

(b) - - 者砵列型

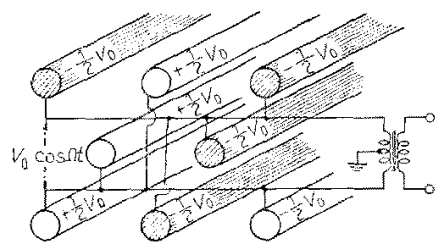

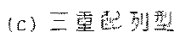

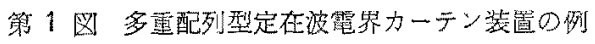

Fig. 1. Examples of multi-array electric curtain devices of standing wave type.

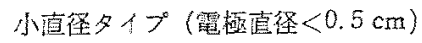

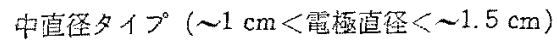

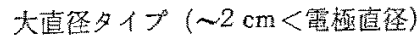

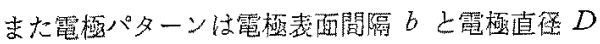
との比 b/D で表わされるか，電界力ーデンの雷気力

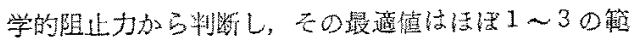

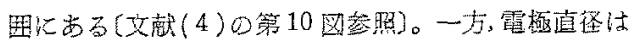

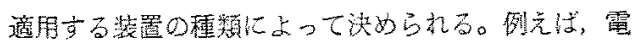
氮管じん哭 (プリダスタ）に適用する䭪合，小直径多 
イプは構造上接触形電界カーテン式 ${ }^{(6)}$ 電気集じん器と

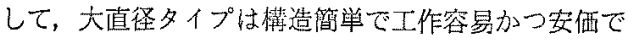
あり，大形集じん器にそれぞれ適用可能である。また 中淔径タイプは上記り中間的な存在であり，小玥ある

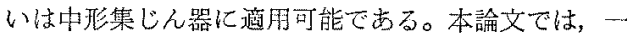
例々して二重配列型するいは二雷配列型電界カーテン

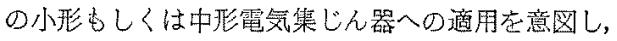
$D=1 \mathrm{~cm}, b / D=2$ の場合に考察を絞ることにした。

\section{2. 千鳥配列型, 二重配列型および三重}

\section{配列型定在波電界カーテンの電界解析}

平面型定在波電界カーテンの籍位分布解析法结，筆 者の一人によって定值代用曘荷法ししてすでに報告さ れている ${ }^{(7)}$ cこれは，あらかじめ等しい線電荷密度 $q(\mathrm{C} / \mathrm{m})$ の代用苜線電荷群安㷛円筒電極内に配置し, その合成電位 $V$ の笔極表面上での值が与えられた電

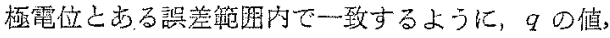
この個数求よび位置を变化さ甘，代用電荷群の合成党 位 $V$ 在用いて空間電位定近似する方法でする。

一方，本研究では電極配列に上る電位分布の非対称

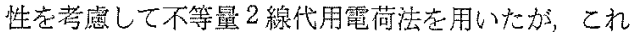
によってここで畉究の対象としたような電極配列につ

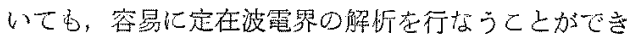

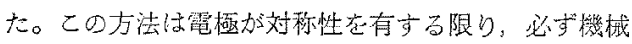
的な手法で近似解が得ら机，乙か本已の解析的な形が

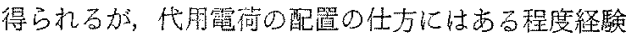
を翼し，試行的な繰り返しが必要である。

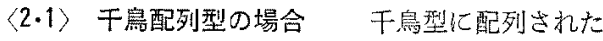
2 組の電極群 $(1,2, \cdots)$ 乙 $\left(1^{\prime}, 2^{\prime}, \cdots\right)$ の間交番琶压 $V_{0} \cos \Omega t$ 专中性点接地で卯加する己，各租の電極電 位はそれぞれ $+1 / 2 \cdot V_{0} \cos \Omega t,-1 / 2 \cdot V_{0} \cos \Omega t$ とな

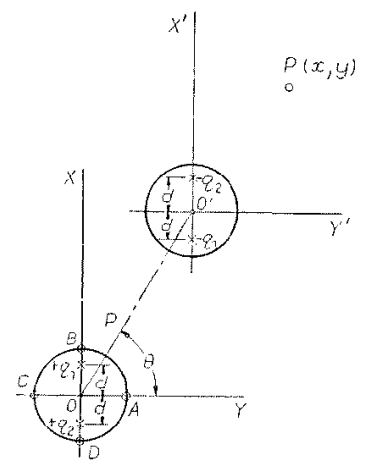

第 2 図 F鳥配列型の円筒霓極群に用いる 代用直線電得群と已の配管

Fig. 2. Location of line substitute-charges within the cylinder-electrodes of zigzag-array type.
万〔第 1 図( a )]。

いま第 2 図に示すように，各円筒電極の中心 $0,0^{\prime} \cdots$ を通る $X$ 軸拈よび $X^{\prime}$ 軸に平行な朝上に $0,0^{\prime}$ 加ら 等しい距㒕 $d$ だけ上下に睢れた2点に，それぞれ1 刘の不等䁷な代用直線電荷 $q_{1}, q_{2}$ 求よ已゙ $-q_{1},-q_{2}$ を配置した場合の点 $P_{0}(x, y)$ ○電位 $V(x, y)$ 梅的 写像によって次のように表わされる。

$$
\begin{aligned}
V(x, y)= & \left(q_{1} / 4 \pi \varepsilon_{0}\right) \ln \left[f_{1}(x, y)\right] \\
& +\left(q_{2} / 4 \pi \varepsilon_{0}\right) \ln \left[f_{2}(x, y)\right] \ldots \ldots
\end{aligned}
$$

だだし

$$
\begin{aligned}
f_{1}(x, y)= & \frac{\cosh ^{2} \frac{\pi}{2 p} \frac{1}{\cos \Theta}(x-p \sin \theta+d)}{\cosh ^{2} \frac{\pi}{2 p} \frac{1}{\cos \theta}(x-d)} * \\
& \frac{-\cos ^{2} \frac{\pi}{2 p} \frac{1}{\cos \Theta}(y-p \cos \Theta)}{-\cos ^{2} \frac{\pi}{2 p} \frac{y}{\cos \Theta}} \\
f_{2}(x, y)= & \frac{\cosh ^{2} \frac{\pi}{2 p} \frac{1}{\cos \Theta}(x-p \sin \Theta-d)}{\cosh \frac{\pi}{2 p} \frac{1}{\cos \theta}(x+d)} \\
& * \frac{-\cos ^{2} \frac{\pi}{2 p} \frac{1}{\cos \Theta}(y-p \cos \theta)}{-\cos ^{2} \frac{\pi}{2 p} \frac{y}{\cos \Theta}}
\end{aligned}
$$

干鳥配列型の電極に与古空閶電位を最屯良く近似さ せるためのパラメータ $d, q_{1}, q_{2}$ の沈定の仕方牥，国 路網に扫けるチェビシェフの手法と類似の考えで行な

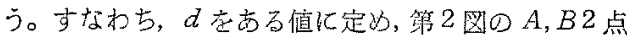

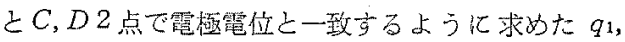
$q_{2}$ の平均值をえのdに対する $q_{1}$ ¿ $q_{2}$ の便とし

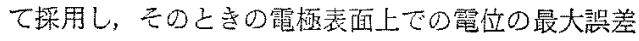
$\varepsilon_{\mathrm{max}}(\%)$ を算出し， $d$ を変北させつつこの手続きを繰 り返し $\varepsilon_{\max }$ が最小となるd，q1，q2の值を求める。

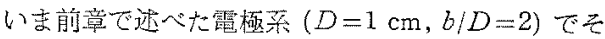

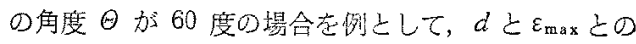
関係第3図儿示す。乙机ら最適な間隔 $d$ は $d_{\text {opt }}$

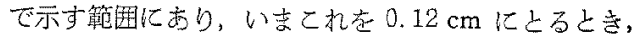
上記電極菜圶近似する最適なパラメー多は次の上うに なる。

$$
\begin{aligned}
& d=0.12 \mathrm{~cm} \\
& q_{1} / 4 \pi \varepsilon_{0}=(+0.29912) \frac{1}{2} V_{0}
\end{aligned}
$$




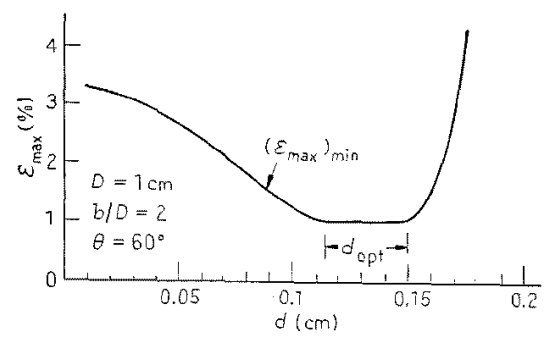

第 3 园 $d\left\llcorner\varepsilon_{\max }\right.$ o関係 (千鳥配列型)

Fig. 3. Location of the substitute charges $d$ vs. maximum error in the surface potential $\varepsilon_{\max }$ (zigzag-array type).

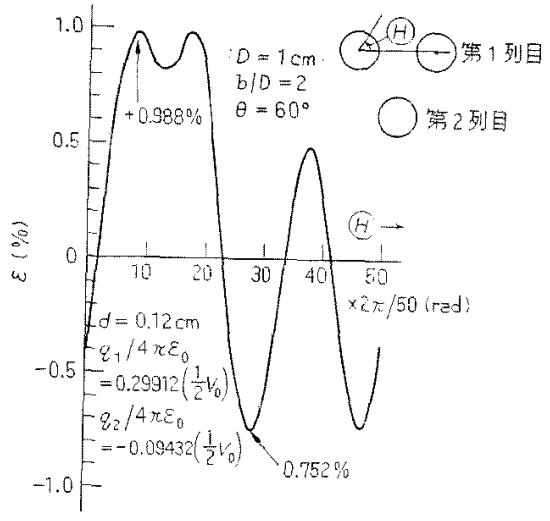

第 4 图 電極電位口計算精度 (千焦配列型)

Fig. 4. Calculation accuracy for electrode surface potential under the optimum selection of substitute-charge densities and their location.

$$
q_{2} / 4 \pi \varepsilon_{0}=(-0.09432) \frac{1}{2} V_{0}
$$

すなわち， $q_{1}$ 主代用電荷とすれ代 $q_{2}$ は $q_{1}$ とは

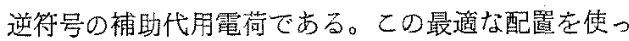
て第 1 列目の電極上の電位の計算猜度を求めたのが第 4 図で，之の誤差は + $0.984 〜-0.752 \%$ の範四にお さまっている。

第 5 四は上記 $d, q_{1}, q_{2}$ を用い $(1) \sim(3)$ 王によっ て計算した空閪霓位の等電位線パターンであり，電極

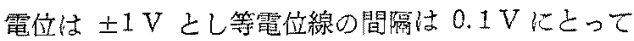
ある。

$\langle 2.2\rangle$ 二重配列型および三重配列型の場合 第 1 园(b)のように二つの平面型電界カーテンを相互に 影響を及ばす間隔で平行に二重に毁列した場合と， (c)図のように三つの平面型電界カーテンを(b)図之 同じ闍䧣で平行に三重に配列した場合を考える。

これらの場合李前章と同様に不等量な代用声線笔荷 列を使用して䨪位関数它求めうる。第 6 図に二重配列

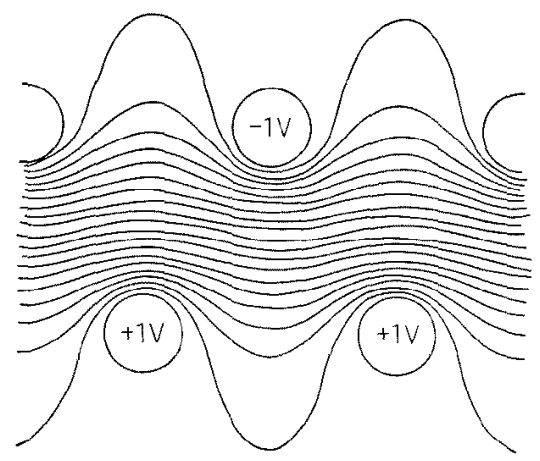

第 5 图 等蕓位線分布（干鳥配列堽）

Fig. 5. Distribution of equi-potential lines (zigzag-array type).

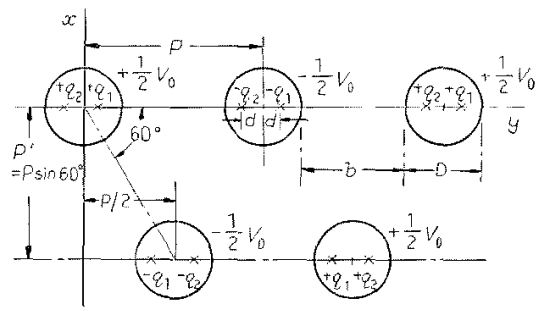

算 6 图 二重配列型の円節電極群に用いる 代用直線霞荷群上その配置

Fig. 6. Location of line substitute-charges within the cylinder electrodes of double-array type.

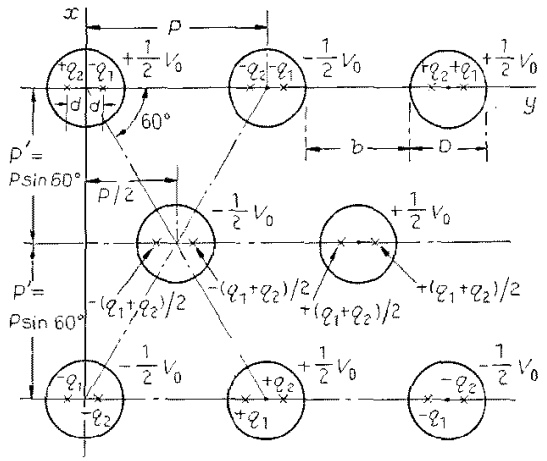

第 7 図 三重配列型の円筒電極群に用いる 代用直楾笔荷群已之の配置

Fig. 7. Location of line substitute-charges within the cylinder electrodes of triple-array type.

型の場合，第 7 凶に三重配列型の場合に採用した代用 苗線電荷と无の配置を示す。これらの配置は多くの配 置を試行的に繰り迡して見いだした最も近以度の良い 2 線電荷配置である。電位分布関数は前音と同様に対 数電虹で与等元れ，

二瑟配列型については

昭 $50-12$ 


$$
\begin{aligned}
& \begin{aligned}
V(x, y)= & \left(q_{1} / 4 \pi \varepsilon_{0}\right) \ln \left(f_{1}(x, y)\right] \\
& \quad+\left(q_{2} / 4 \pi \varepsilon_{0}\right) \ln \left[f_{2}(x, y)\right] \ldots \ldots(4)
\end{aligned} \\
& \text { ただし } \\
& f_{1}(x, y) \\
& =\frac{\cosh \frac{\pi}{p} x+\cos \frac{\pi}{p}(y-d)}{\cosh \frac{\pi}{p} x-\cos \frac{\pi}{p}(y-d)} \\
& \quad \times \frac{\cosh \frac{\pi}{p}\left(x+p^{\prime}\right)+\cos \frac{\pi}{p}\left(y+d+\frac{p}{2}\right)}{\cosh \frac{\pi}{p}\left(x+p^{\prime}\right)-\cos \frac{\pi}{p}\left(y+d+\frac{p}{2}\right)}
\end{aligned}
$$

$f_{2}(x, y)$

$$
\begin{aligned}
= & \frac{\cosh \frac{\pi}{p} x+\cos \frac{\pi}{p}(y+d)}{\cosh \frac{\pi}{p} x-\cos \frac{\pi}{p}(y+d)} \\
& \times \frac{\cosh \frac{\pi}{p}\left(x+p^{\prime}\right)+\cos \frac{\pi}{p}\left(y-d+\frac{p}{2}\right)}{\cosh \frac{\pi}{p}\left(x+p^{\prime}\right)-\cos \frac{\pi}{p}\left(y-d+\frac{p}{2}\right)}
\end{aligned}
$$

三重配列型については

$$
\begin{aligned}
V(x, y)= & \left(q_{1} / 4 \pi \varepsilon_{0}\right) \ln \left[f_{1}(x, y)\right] \\
& +\left(q_{2} / 4 \pi \varepsilon_{0}\right) \ln \left[f_{2}(x, y)\right] \\
& +\frac{q_{1}+q_{2}}{2} / 4 \pi \varepsilon_{0} \cdot \ln \left[f_{3}(x, y)\right]
\end{aligned}
$$

ただし

$f_{1}(x, y)$

$$
\begin{aligned}
= & \frac{\cosh \frac{\pi}{p} x+\cos \frac{\pi}{p}(y-d)}{\cosh \frac{\pi}{p} x-\cos \frac{\pi}{p}(y-d)} \\
& \times \frac{\cosh \frac{\pi}{p}\left(x+2 p^{\prime}\right)-\cos \frac{\pi}{p}(y+d)}{\cosh \frac{\pi}{p}\left(x+2 p^{\prime}\right)+\cos \frac{\pi}{p}\left(y+d^{\prime}\right)}
\end{aligned}
$$

$f_{2}(x, y)$

$$
\begin{aligned}
= & \frac{\cosh \frac{\pi}{p} x+\cos \frac{\pi}{p}(y+d)}{\cosh \frac{\pi}{p} x-\cos \frac{\pi}{p}(y+d)} \\
& \times \frac{\cosh \frac{\pi}{p}\left(x+2 p^{\prime}\right)-\cos \frac{\pi}{p}(y-d)}{\cosh \frac{\pi}{p}\left(x+2 p^{\prime}\right)+\cos \frac{\pi}{p}(y-d)}
\end{aligned}
$$

$$
\begin{aligned}
f_{3}(x, y) & \frac{\cosh \frac{\pi}{p}\left(x+p^{\prime}\right)+\cos \frac{\pi}{p}\left(y-d+\frac{p}{2}\right)}{\cosh \frac{\pi}{p}\left(x+p^{\prime}\right)-\cos \frac{\pi}{p}\left(y-d+\frac{p}{2}\right)} \\
& \times \frac{\cosh \frac{\pi}{p}\left(x+p^{\prime}\right)+\cos \frac{\pi}{p}\left(y+d+\frac{p}{2}\right)}{\cosh \frac{\pi}{p}\left(x+p^{\prime}\right)-\cos \frac{\pi}{p}\left(y+d+\frac{p}{2}\right)}
\end{aligned}
$$

となる。

いま一例として前章と同様の電極パターンについ て,チェビシェフ近似の手法に上り種々の間隔 $d$ に 対する $q_{1}, q_{2}$ 求め，それ基づいて算出した第 1 列目 の電極列纪标ける電極電位の最大䛊差 $\varepsilon_{\max }$ 之間隔 $d$ の関係を第 8 图保示す。電極笔位を最良く近似する パラメータは次の上おりである。

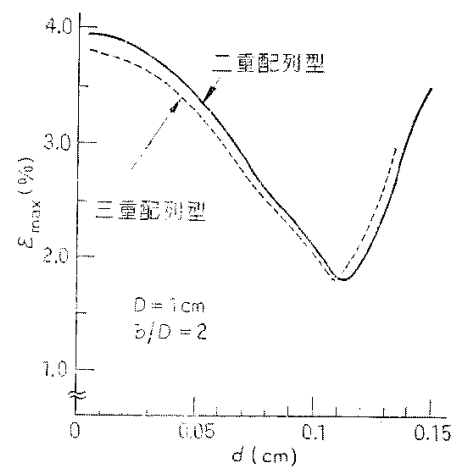

第 8 図 $d$ と $\varepsilon_{\max }$ の関係 (二重配列型およひ 三重配列型)

Fig. 8. Location of the substitute-charges $d$ vs. maximum error in the surface potential $\varepsilon_{\text {max }}$ (double-array type and triple-array type).

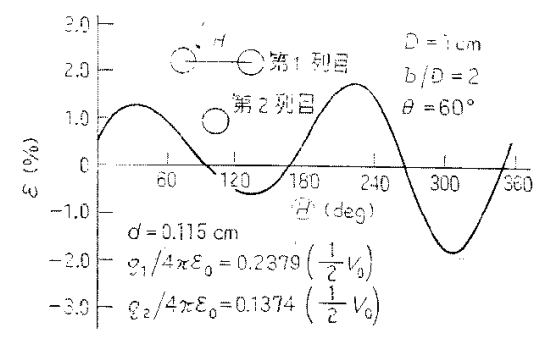

第 9 四 電極電位の計算精度 (二㻎配列型)

Fig. 9. Calculation accuracy for electrode surface potential under the optimum selection of substitute-charge densities and their location (double-array type). 


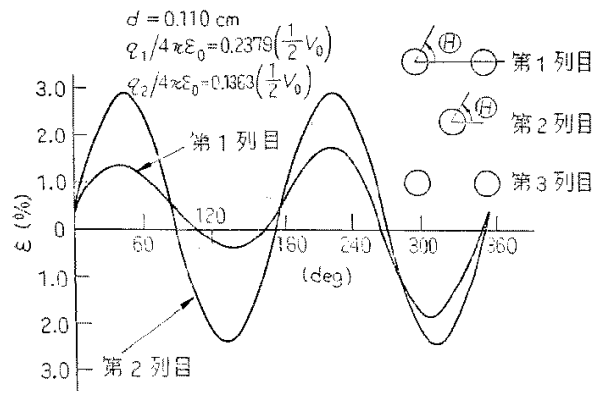

第 10 図 電極電位の言算精度 (三重配列型)

Fig. 10. Calculation accuracy for electrodes surface potential under the optimum selection of substitute-charge densities and their location (triple-array type).

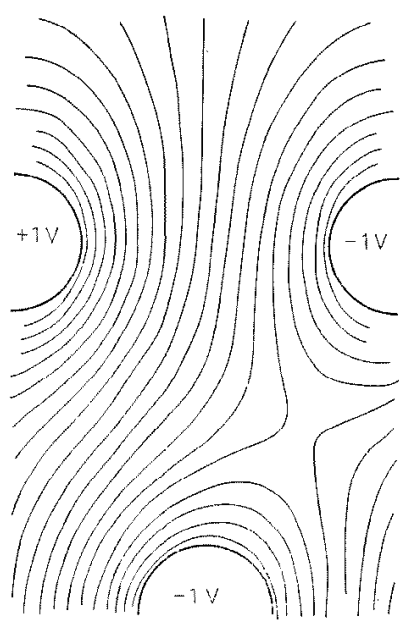

第 11 图 等雪位線分布（二重配列型）

Fig. 11. Distribution of equi-potential lines (double-array type).

$$
\begin{aligned}
& \text { 二露配列型の場合 } \\
& a=0.115 \mathrm{~cm} \\
& q_{1} / 4 \pi \varepsilon_{0}=0.2379\left(1 / 2 \cdot V_{0}\right)(\mathrm{V}) \\
& q_{2} / 4 \pi \varepsilon_{0}=0.1374\left(1 / 2 \cdot V_{0}\right)(\mathrm{V}) \\
& d=0.111 \mathrm{~cm} \\
& q_{1} / 4 \pi \varepsilon_{0}=0.2379\left(1 / 2 \cdot V_{0}\right)(\mathrm{V}) \\
& q_{2} / 4 \pi \varepsilon_{0}=0.1365\left(1 / 2 \cdot V_{0}\right)(\mathrm{V})
\end{aligned}
$$

二重配列型の第 1 列目の電極全周にわたる計算精度 を第 9 图K，三重配列型の第 1 列目之笨 2 列目の電桠 全周にわたる計算整度を第 10 园に示す。また籍 11 图, 第 12 図はそれぞれ等䨘位線分布在，電極電位 $\pm 1 \mathrm{~V}$, 等電位線間隔 $0.1 \mathrm{~V}$ として求めたものである。

昭 $50-12$

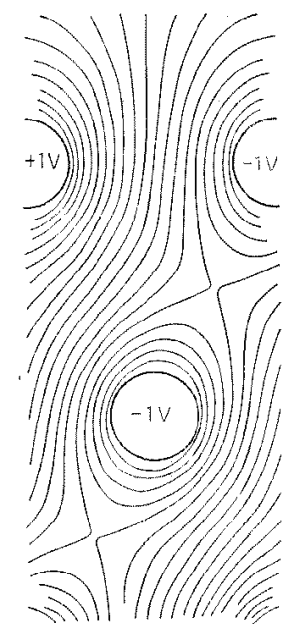

第 12 図 等電位線分布（三重配列型）

Fig. 13. Distribution of equi-potential lines (triple-array type).

\section{3. 阻止ポテンシャルすよび阻止力の分布}

定在波電界力ーテンの最李重要な電気力学的特性量

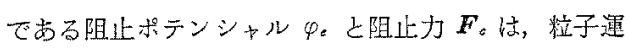
動方程式の楾形近似解を用い次式のように表わされ $3^{(1)-(3)}$

$$
\begin{aligned}
\varphi_{e} & =\frac{1}{4} \frac{Q^{2}}{M \Omega^{2}\left\{1+(6 \pi \eta A / M Q)^{2}\right\}} E^{2} \\
\boldsymbol{F}_{c} & =-\operatorname{grad} \varphi_{e} \ldots \ldots \ldots \ldots \ldots \ldots \ldots \ldots
\end{aligned}
$$

ただし

$$
E^{2}=(-\partial V(x, y) / \partial x)^{2}+(-\partial V(x, y) / \partial y)^{2}
$$

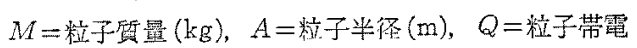
量 (C)， $\Omega=$ 電源角周波数 ( $\mathrm{rad} / \mathrm{s}$ )， $\eta=$ 空棂粘性係数 $\left(\mathrm{N} \cdot \mathrm{s} / \mathrm{m}^{2}\right), V(x, y)=$ 電位関数 $(\mathrm{V}) 〔(1) \sim(10)$ 式〕 せて $\varphi_{e}, F_{t}$ は次の三つの因子て赫成されている。

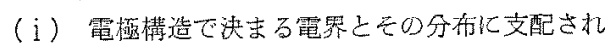
る因子…… $E^{2}$ 极上び $\operatorname{grad} E^{2}$

(ii) 物理パラメータに支眠さ机る因子小…… $\Omega$

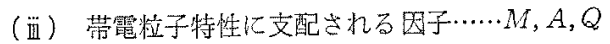

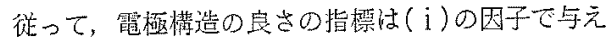
られ，電極設計にあたってはとの因子を最大にするパ ターン老胃つける必要がある。これに関連し来際印 加できる最大電压 $V_{\mathrm{max}}$ 恬溉㥛の破烄電界強度 $E_{b}$ で 決まる。

すなわち。

$$
V_{\text {max }}=E_{b} \cdot b \cdot \zeta
$$

ここで， $b$ は電極表面閫げき，とは電界利用率で電極 
表面の最大電界強度を $E_{\mathrm{max}}$ として次式で定義される。

$$
\zeta=\left(V_{0} / b\right) / E_{\max } \quad[-]
$$

$E_{\max }$ は (1) (10) 式から求められ, 各電極系につい てらの值は次のようになる。

千鳥配列型 $\zeta=0.58$, 二重配列型 $\zeta=0.544$

三重配列型 $\zeta=0.57$

一方，乙れらの電極系の破填電界強度の近似值とし

て, 䈉者の一人が求めた平政型の実鈳值を使うと $D$ $\doteqdot 1 \mathrm{~cm}, b / D=2$ の場合 $E_{b} \fallingdotseq 38 \mathrm{kV} / \mathrm{cm}$ となり ${ }^{(4)}$, 最大印加電圧は各電極系について次の上うに推定され る。

干烏配列型 $V_{\max } \fallingdotseq 44 \mathrm{kV}$, 二重配列型 $V_{\max }=41.3$ $\mathrm{kV}$ ，三重配列型 $V_{\max } \fallingdotseq 43.3 \mathrm{kV}$

畞加電压によって阻止特性の絶対值に善が生ずる が，電極構成の及ぼす影響は正負電極に単位の電位 $( \pm 1 \mathrm{~V})$ を与えた場合の $E^{2}$ 和よび $\left(-\operatorname{grad} E^{2}\right) の$ 電極 近傍の分布状態で判定でき，それぞれサフィックス 1 を付け基集阻止ポテンシャル，基準阻止力と名づける。

第 13 図は干鳥配列型の等基準阻止ポテンシャル線 を，第14四㹥二重配列型のそれて表わす。これらは，

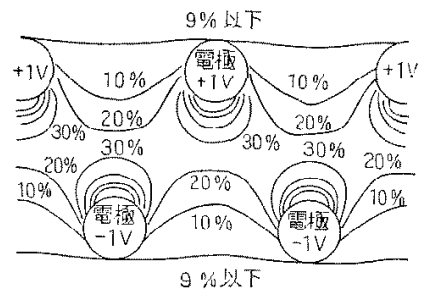

第 13 因 基準阻此ポテンシャル分布(千鳥配列型)

Fig. 13. Distribution of standard repulsion potential ( $\left.E^{2}\right)$ (Zigzag-array type).

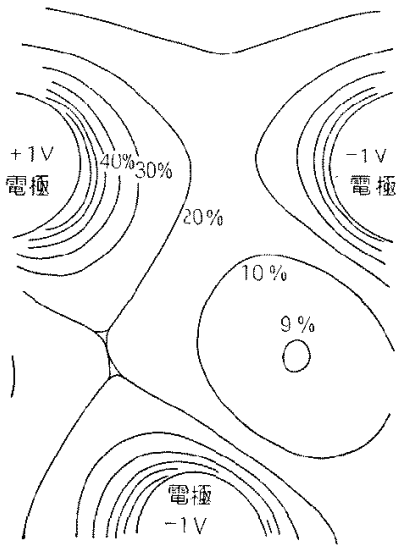

第 14 図 基準阻止ポテンシャル分布 (二重配列型)

Fig. 14. Distribution of standard repulsion potential $\left(E^{2}\right)$ (Double-array type).

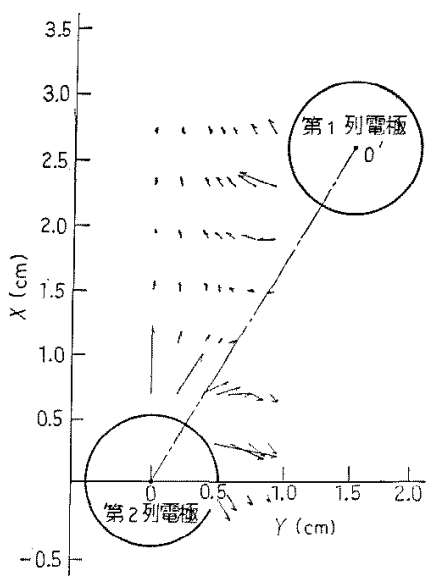

第 15 四 基準阳止力分布 (干鳥配列型)

Fig. 15. Distribution of standard repulsion force (Zigzag-array type).

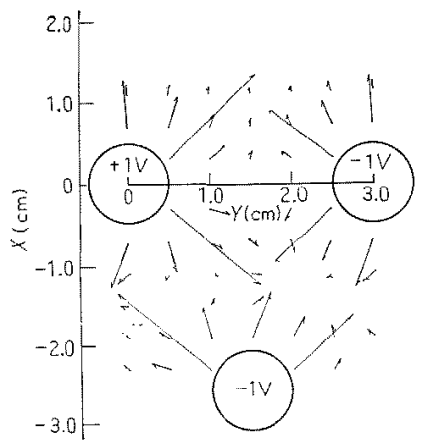

第 16 图 基準阻止力分布 (二重配列型)

Fig. 16. Distribution of standard repulsion force (Double-array type).

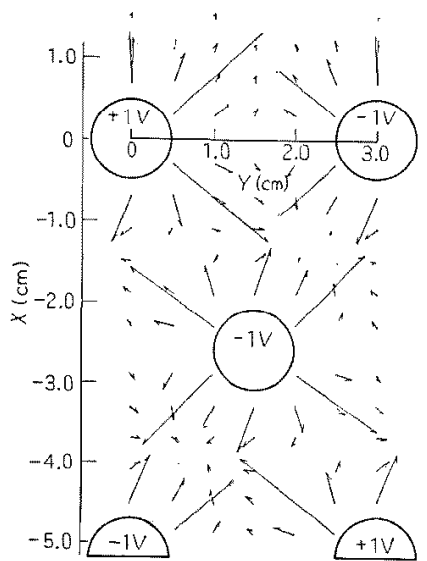

第 17 区 基準阻止力分布 (三重配列型)

Fig. 17. Distribution of standard repulsion force (Triple-array type). 
いずれす電位関数を使って笔界分布加ら $E_{1}{ }^{2}$ を計算 し、最大值を基準化し゚ーセント表示したものである。 また，基準阻止力の大ささの絶対值 $\left|\boldsymbol{F}_{: 1}\right|$ の分布之 その方向 $\theta$ はそ机でれ次式で表わされる。

$$
\begin{aligned}
& \left|\boldsymbol{F}_{c 1}\right|=\sqrt{\left(-\partial E_{1}^{2} / \partial x\right)^{2}+\left(-\partial E_{1}^{2} / \partial y\right)^{2}} \\
& \theta=\tan ^{-1}\left[\left(\partial E_{1}^{2} / \partial y\right) /\left(\partial E_{1}^{2} / \partial x\right)\right] \ldots \ldots . .
\end{aligned}
$$

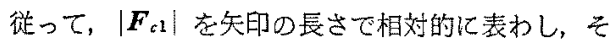
の作用方向を矢印の方向之一致させ，加つ作用位置索 知の始点として，千鳥配列型，二重配列型拈よび三 重配列型に対してアナログ的に表示したのが第 15 図 〜第 17 図である。

第 13 図〜第 17 図を総合的汇見ると，千鳥配列型は 基準ポテンシャルの峠が異極性電極にはさまれた空間 だけにあり，上方から飛来した帯電粒子は上部電極群 を通り拔け二つの電極群の間に入り込み，こてで外力 に抗して保持される。これを阻止力でみると，上下電 極中心線の队侧上方では外力に対して粒子を阻止し， 電極間中心に絞り込むように鹳いていることに対応し ている。

また二重配列型，三重配列型は内部に四重極が现成 されておる，その中心がエネルギー的に最も低く，て こに入り込えだ㜔子は外力に抗して保持される。一 万, 基準阻止力では第 1 列目の平面型に批汀る電極間 中心の最弱部定，第2列日括よび第3列曰の電極群か 文字ど柗り二瑟，三重にバックアップしている。

\section{4. $\boldsymbol{X}$ 軸に平行な直楾に沿っての $\boldsymbol{E}_{1}{ }^{2}$ と $-\partial \boldsymbol{E}_{1}{ }^{2} / \partial x$ の分布}

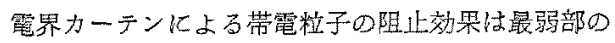
阻止力江支配され, 平面型では電極問の中央線上飞最 弱部があり，この線上ての阻止力が議論されている゙ 今回の解析牥, 便宜上干鳥配列型上二重配列型は下

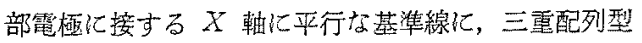
は中間部電極に按する $X$ 軸に平行な基準線に沿って, 阻止特狌の変化を調べた。

第 18 図は $E_{1}{ }^{2}$ の基集線 $A B$ 上の分布を示す。特 徵的事がらは，三重配列型は他の配列方式に比較し， 第2 列目近傍では前後の電極列の干涉で $E_{3}^{2}$ は滛加 に大きくなっていることである。

第 19 図は基準線 $A B$ 上の $\left(\boldsymbol{F}_{61}\right)_{x}=-\partial E_{1}^{2} / \partial x$ の 分布を示す。二箸配列型と三重配列型は第 1 列目近傍

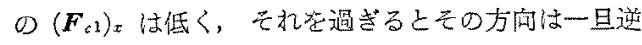
枟するが，第2 列目前面で再び正となり急激化大きく なっている。一方，千鳥配列型の $\left(\boldsymbol{F}_{c 1}\right)_{x}$ 分有はブロ ードで值す小さく，第 1 列目での阻止力はなく電極中 間部でしか阻止能力はない。

昭 $50-12$

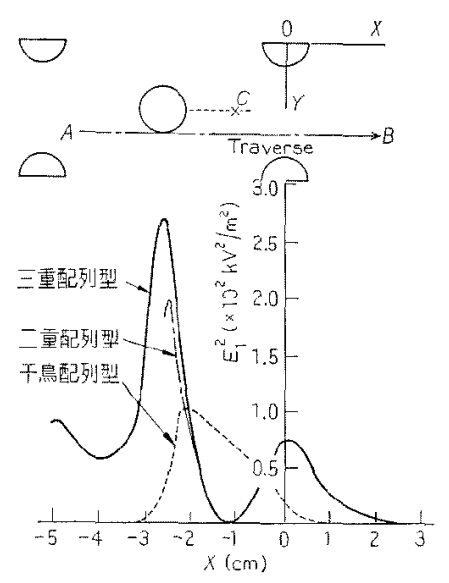

第 18 図電極中間領域刀 $x$ 㛙江平行な直線 $A B$ 上での基準阻止ポテンシャルの変化

Fig. 18. Change of standard repulsion potential along a line $A B$ parallel to $x$-axis.

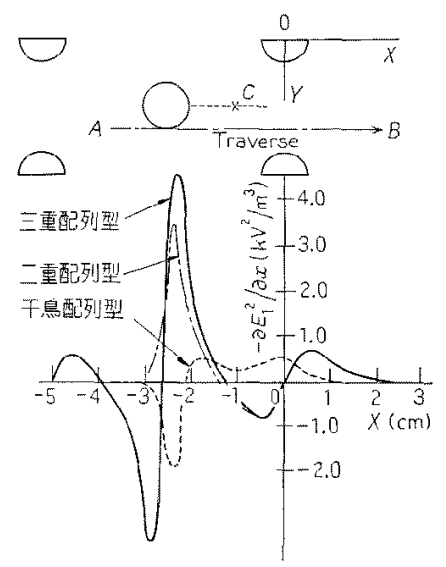

第 19 図 電極中間領域 $x$ 本に平行な盲線 $A B$ 上で基準阻止力の $x$ 成分の変化

Fig. 19. Change of the $x$-component of standard repulsion force along a line $A B$ parallel to $x$-axis.

\section{5. 阻止カの具体的な数値例}

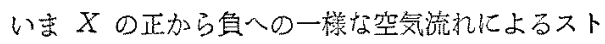
一クス粘性力を带電粒子に及洋方外力とし, 上記電界 カーテンでどの程度の風速まで粒于を流れに司搬され ずに保持てきるか疮検討する。と机は X方向の実阻 止力 $\left|\boldsymbol{F}_{c}\right|_{\text {。 }}$ 上外力とを等監して得引れる阻止可能な 最大風速 $U_{\max }$ で次の上うに表わされる。

$$
U_{\max }=\frac{1}{6 \pi} \eta \frac{1}{4} M \frac{Q^{2}}{M Q^{2}\left\{1+(6 \pi \eta A / M \Omega)^{2}\right\}}
$$




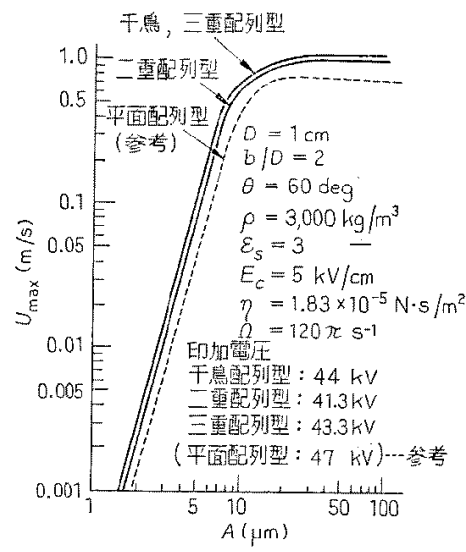

第 20 図 理論限界風速 $U_{\max }$ 之粒子半经 $A$ の関係（常温常王の空気）

Fig. 20. Theoretical critical gas velocity as a function of particle radius (air at normal temperature and pressure).

$$
\times\left(\frac{1}{2} V_{\max }\right)^{2}\left(-\frac{\partial E_{1}{ }^{2}}{\partial x}\right)
$$

ここで，粒子はコロナ放電によるイオン衙突で理覦 飽和電荷量 ${ }^{(8)}$ 在持つと仮定する。すなおち

$$
Q=4 \pi \varepsilon_{0}\left\{3 \varepsilon_{s} /\left(\varepsilon_{s}+2\right)\right\} A^{2} E_{c} \text { (C) }
$$

ただし $\varepsilon_{0}=8.85 \times 10^{-12}(\mathrm{~F} / \mathrm{m}), \varepsilon_{s}=$ 粒子比誘電率〔一〕， $E_{c}=$ 荷雪空間の電界強度 $(\mathrm{V} / \mathrm{m})$

また，粒子質㱬 $M$ は粒子密度 $\rho\left(\mathrm{kg} / \mathrm{m}^{3}\right)$ より次式 で求める。すなわ方

$$
M=4 \pi \rho A^{3} / 3(\mathrm{~kg})
$$

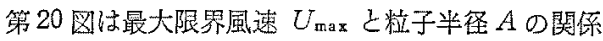
を，最大印加電压 $V_{\max }$ の場合に求好たあのである。 ただし，阻止位琵は第 18 図，第 19 図のC点とした。 二重配列型之三重配列型估平面型の性能走補てんして いるが，上記位置で比較する限りは，これら3者間の $U_{\text {max }}-A$ 特性にほとんど苃がない。しかし，第 13 図 加第 19 図行された阻止力の空間分布考慮する と, 総合阻止特性としては線形近似理諭を楝用して評 価する限り三重配列㤠が䬺机ている。

また，符 20 图から上部寸法の 4 種類（亚面型を含 む)の電界カーテンについて大略次の結論が得られる。

(i) 風速を $0.5 \sim 1.0 \mathrm{~m} / \mathrm{s}$ 程度（電気笨じん装置 の風遭）にとると，半径 $10 \sim 20 \mu \mathrm{m}$ メ上の粹子しか 阻止できない。

(ii) 風速を $2 \sim 5 \mathrm{~cm} / \mathrm{s}$ 程度（万過集しん装置の風

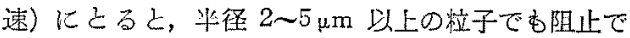
きる。

说って，集じん装㽞として（i)の領域で使用する場
合，電気萝じん装置でつち打時などに再飛散してくる ダスト（凝集し阻大化している）を捕捉するための後 置集じん，あるいは雷気集じん装置の入口ダスト負荷 を整減するための前置集じんの用途が避している。す た（ ii）の領域で使用する易合には，乃過集じん装置の 万材の前面または内部に配睨し，ダスト負荷軽隇ころ 過材表面たい皘ダストの払い落し月网 ${ }^{(6)}$ として使用する のに適している。

以上の解析は線形近似理論に基ついており，それ目 体に適用限界がある。更にダストは(16)式の理諭值ま で荷嘋されるととを前提としているが，乙れは種々の 理由*で困難である。まt温度が高くなると火花電压 $V_{\max }$ が下がるので特性低下が生じうる。しかし，とれ らの因子を念頭に置く限り，二重配列型ちるいは三重 配列型電界カーテンの実用化あたって，その使用法，設 計指針を得るには上述の解析は有用であると信ずる。

\section{6. まとめ}

平面型電界カーテンを発展させ,二重配列型, 三重配 列型電界カーテンとし，不等量代用電荷法を適用し， その空間電位を 2 3\% の精度で計算できる表示式を 求め, 線形近似理諭の立場で絃子阻正能力を表放す基 準阻止ポテンシャルと莱準阻止力を計算し，こ扎らの 配列は平面型の特性をハッックアップしていることを確 認した。露に，粒子がイオン衙突による理諭飽和電荷 量索うる場合，各粒子直径隹対する限界風速を求め， 特に三重配列型は俱九た阻止能力がある点を明らかに した。なお，粒子の実際の電荷量は理諭飽和値に達し ない場合が多く，笓界カーテンの性能は粒子荷掌装葍 の性能に大きく支配される。この問題を含的非線形理 論による䉪界カーテンの集じん淩置への詳細な展開は 別に報告する。

最後に, 本研究に賜わった高津章区（安川電機製 作所取楴役)，己の他関係各位のご援助に衰心より感 啲する次第である。

(昭和 49 年 12 月 10 日受付, 同 50 年 6 月 23 日再受付)

\section{文献}

(1) S. Masuda, K. Fujibayashi \& K. Ishida: Advances in Static Electricity, Vol. 1, p. 398, (1970) Auxilia S. A., Brussels

(2) ibid.: Staub-Reinhaltung der Luft, Bd. 30, Nr. 11, S. 449 (1970-11)

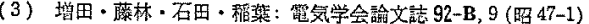

(4) 增田?淞本: 同上 93-B，41（昭 48-2)

(5) 增田 - 松本 ·河久津: 同上 93-B，48(昭 48-2)

(6) S. Masuda \& Y. Matsumoto: Dechema-Monographien 72. 293 (1974)

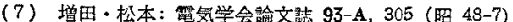

(8) H.J. White: AlEE Trans. 70, 1186 (1951)

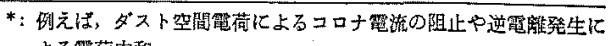
よる麗苚中租 